DOI.

https://doi.org/10.22219/fths.v3i1

Received: Desember 2019

Accepted: Januari 2019

Available online: Februrari 2020

\title{
Kajian Edible Coating Berbasis Kolang-Kaling Dengan Penambahan Bahan Pengental Dari Sumber Alami (Pati dan Pektin) dan Sintetis (CMC) Yang Diaplikasikan Pada Dodol
}

\author{
Dwi Pramsiska ${ }^{1}$, Noor Harini ${ }^{1 *}$, Sri Winarsih ${ }^{1}$, Hanif Alamudin Manshur ${ }^{1}$ \\ ${ }^{1}$ Program Studi Teknologi Pangan, Fakultas Pertanian Peternakan, Universitas \\ MuhammadiyahMalang, Malang, Indonesia \\ *Corresponding author email: harini@umm.ac.id
}

\begin{abstract}
The purpose of this study was to determine the effect of the type of thickener on the quality of edible coatings, the effect of the concentration of thickener types on the quality of edible coatings applied to dodol, and find the best treatment of edible coatings that can increase the shelf life of dodol. The research was arranged in a Nested Randomized Design method that consisting of two factors. First factor that became the nest was variation of thickener $(P)$ with treatment level (Pati, Pectin and CMC) and second factor that became nested namely variation of thickener concentration (K) with treatment level $(1 \%, 1.5 \%$ and $2 \%)$. The results showed that addition of pectin $2 \%$ as the best treatment has a viscosity of $238.2 \mathrm{cP}$ and the ability to protect dodol on the 6th day storage can be observed at water content of $26.98 \%$ which is close to SNI which is equal to $20 \%$, TPC (Total Plate Count) $4.9 \times 10^{4} \mathrm{Cfu} / \mathrm{g}$ which is close to the TPC number on SNI of $1 \times 10^{4}$ Cfu / g, FFA (Free Fatty Acid) of 1.06\% which does not exceed the SNI limit of $10.5 \%$, texture of $8.18 \mathrm{~N} / \mathrm{mm}$, the aroma score of 3.53 is a bit rancid, the appearance score is 5.23 which means neutral and the preferences score is 6.07 which means a little like.
\end{abstract}

Keyword: CMC, dodol, edible coating, pectin, thickening, starch

\section{PENDAHULUAN}

Aren adalah tanaman perkebunan yang sangat potensial untuk mengatasi kekurangan pangan. Hasil produksi tanaman aren yang dapat dimanfaatkan, seperti buah aren muda diolah menjadi kolang-kaling. Pemanfaatan kolangkaling masih sangat terbatas. Kolang-kaling dapat dijadikan sebagai dasar pembuatan edible coating karena memiliki kandungan serat yang tinggi mencapai $10,524 \%$. Selain itu, karbohidrat yang terkandung dalam biji aren adalah galaktomanan yang terkandung sebesar $4,15 \%$ (Tarigan, 2009). Sehingga dengan adanya pemanfaatan kolang-kaling sebagai bahan dasar edible coating, diharapkan mampu untuk meningkatkan nilai ekonomi dari kolang-kaling.

Edible coating merupakan lapisan tipis terbuat dari bahan yang dapat dimakan dan memiliki fungsi untuk memberikan perlindungan yang selektif terhadap gas, air serta kerusakan mekanis. Penelitian yang telah dilakukan oleh 
Sitompul, (2017), melaporkan bahwa edible film berbasis kolang-kaling tanpa penambahan komponen lain, menghasilkan lapisan yang tipis dan mudah rapuh. Berdasarkkan hal tersebut, perlu penambahan komponen lain yang juga berfungsi sebagai bahan pengental. Bahan pengental terdiri dari dua macam yaitu bahan pengental alami dan bahan pengental sintetis. Salah satu contoh bahan pengental sintetis yang diizinkan digunakan dalam aplikasi makanan adalah CMC sedangkan contoh bahan pengental alami adalah pati dan pektin. Efektivitas edible coating berbasis kolang-kaling dengan bahan pengental yang berbeda, dapat dilihat dengan melakukan aplikasi pada produk makanan yaitu dodol.

\section{METODOLOGI PENELITIAN}

Bahan

Bahan-bahan yang digunakan dalam pembuatan edible coating adalah kolang-kaling berwarna putih bersih yang didapatkan dari pasar Blimbing Malang, sorbitol, aquades, bahan pengental alami hasil ekstraksi kulit pisang berupa pektin dan pati hasil ekstraksi dari singkong, serta bahan pengental sintetis CMC yang didapatkan dari toko bahan kimia di Malang.

Alat

Alat-alat yang digunakan dalam pembuatan edible coating antara lain timbangan analitik (Pioneer Ohaus PA413), colour reader CR-10 Konuca Milnolta, oven (WTC Binder 7200 tipe E53 no. 89749), Termometer, viscometer (VT-RiOn type t225).

\section{Pembuatan Edible Coating}

Pembuatan larutan edible coating berbasis kolang-kaling dan pengaplikasiannya pada dodol mengikuti metode Sitompul (2017) yang dimodifikasi. Kolang-kaling dicuci bersih kemudian dihancurkan menggunakan blender dengan penambahan air (1:1). Bubur kolang- kaling ditimbang sebanyak $20 \mathrm{~g}$ dan dipanaskan didalam $100 \mathrm{~mL}$ aquades dengan suhu $70^{\circ} \mathrm{C}$ selama 5 menit. Bubur kolang-kaling yang telah larut, selanjutnya ditambahkan bahan pengental sesuai perlakuan (pati, pektin, dan CMC) dengan konsentrasi (1\%, $1,5 \%, 2 \%)$ dilakukan pengadukan selama 15 menit. Selanjutnya ditambahkan sorbitol (1\%) disertai dengan pengadukan selama 5 menit.

\section{Pembuatan Dodol}

Pembuatan dodol mengikuti metode Hariyadi, (2008) yang dimodifikasi. Tahap awal pembuatan dodol adalah menyiapkan bahan- bahan yang dibutuhkan seperti $250 \mathrm{~g}$ gula merah, $100 \mathrm{~g}$ gula pasir, $250 \mathrm{~g}$ tepung ketan, $50 \mathrm{~g}$ tepung beras, $400 \mathrm{~mL}$ santan, garam. Bahan yang dimasak pertama kali adalah gula yang dipanaskan hingga mencair. Gula yang telah mencair, dicampurkan dengan tepung dan cairan (santan kental). Proses pengadukan dilakukan secara 
terus menerus dengan api kecil hingga dodol mengental dan matang. Dodol yang telah matang, dituang dalam loyang dan didinginkan, kemudian dipotong dengan ukuran dan berat yang seragam, kemudian aplikasi pada dodol yang dilakukan dengan cara dicelupkan ke dalam larutan edible coating selama 15 detik dan dikeringanginkan selama 1 menit. Kemudian dodol dicelupkan kembali dalam larutan edible coating selama 15 detik. Dodol yan telah terlapisi edible coating, disimpan pada suhu ruang dan dilakukan analisis pada hari ke-0, 3 dan 6.

\section{Parameter Penelitian}

Parameter yang diamati adalah viskositas larutan edible coating kadar air di hari ke-0, susut bobot, FFA (Free Fatty Acid), TPC (Total Plate Count), tekstur, warna (L,a,b), organoleptik (aroma, kenampakan dan kesukaan) selama penyimpanan hari ke-0, 3 dan 6 . Dari 27 perlakuan akan didapatkan perlakuan terbaik dan akan dibandingkan dengan kontrol (perlakuan tanpa penambahan bahan pengental).

\section{Rancangan Percobaan dan Analisa Data}

Penelitian disusun dalam metode Rancangan Nested terdiri atas dua faktor. Faktor I (penyarang) yaitu variasi bahan pengental (P) dengan level perlakuan (Pati, Pektin dan CMC) dan faktor II (tersarang) yaitu variasi konsentrasi bahan pengental $(\mathrm{K})$ dengan level perlakuan (1\%, 1,5\% dan 2\%). Analisis data penelitian menggunakan analisis ragam dan dilanjutkan dengan uji DMRT (Duncan Multiple Range Test). Penentuan perlakuan terbaik menggunakan metode indeks efektivitas. Hasil perlakuan terbaik kemudian dibandingkan dengan kontrol (edible coating tanpa bahan pengental) menggunakan uji T.

\section{HASIL DAN PEMBAHASAN \\ Viskositas Larutan Edible Coating}

Jenis dan konsentrasi bahan pengental pati, pektin dan CMC berpengaruh sangat nyata terhadap viskositas larutan edible coating. viskositas larutan edible coating dapat dilihat pada Tabel 1. Berdasarkan Tabel 1 dapat dlihat bahwa viskositas larutan coating tertinggi adalah perlakuan CMC sedangkan yang terendah adalah pati. 
Tabel 1. Viskositas larutan edible coating

\begin{tabular}{ll}
\hline Perlakuan & Viskositas $(\mathrm{cP})$ \\
\hline Pati $1 \%$ & $128,7 \mathrm{a}$ \\
Pati $1,5 \%$ & $132,2 \mathrm{a}$ \\
Pati $2 \%$ & $134,2 \mathrm{a}$ \\
\hline Pektin $1 \%$ & $211,8 \mathrm{~b}$ \\
Pektin $1,5 \%$ & $220,5 \mathrm{~b}$ \\
Pektin $2 \%$ & $238,8 \mathrm{c}$ \\
CMC $1 \%$ & $252,2 \mathrm{~d}$ \\
CMC $1,5 \%$ & $259,6 \mathrm{~d}$ \\
CMC $2 \%$ & $318,8 \mathrm{e}$ \\
\hline
\end{tabular}

Angka yang diikuti oleh huruf abjad yang berbeda menunjukkan perbedaan nyata berdasarkan uji Duncan $\alpha=1 \%$.

Viskositas larutan coating cenderung meningkat dengan semakin bertambahnya konsentrasi bahan pengental yang ditambahkan. Terbentuknya larutan yang kental disebabkan karena adanya penambahan bahan pengental yang merupakan hidrokoloid yang dapat mengikat air. Menurut Fennema (2008) air akan terikat melalui ikatan hidrogen dengan gugus hidroksil pada hidrokoloid membentuk konformasi double heliks sehingga membentuk struktur tiga dimensi. Sehingga keadaan larutan lebih mantap dan terjadi peningkatan viskositas.

\section{Perubahan Dodol Selama Penyimpanan}

Perubahan fisikokimia dan mikrobiologi dodol selama penyimpanan dapat dilihat pada Tabel 2, 3, 4, dan 5 sedangkan organoleptik (kenampakan, aroma, kesukaan) dapat dilihat pada Gambar 1. Secara umum kadar air dodol mengalami penurunan selama penyimpanan. Penurunan kadar air dapat disebabkan karena penyimpanan yang dilakukan pada suhu ruang sehingga menyebabkan terjadinya kesetimbangan antara produk dengan kondisi lingkungan yang ada diluar produk. Menurut Riska (2018) pada dodol juga terjadi penguapan akibat pengaruh suhu penyimpanan. Penyimpanan yang dilakukan pada suhu $25^{\circ} \mathrm{C}$ sampai dengan suhu $30^{\circ} \mathrm{C}$ dapat menyebabkan dehidrasi akibat perpindahan uap air dari produk ke lingkungan sehingga kadar air akan menurun. 
Tabel 2. Perubahan Kimia Dodol Selama Penyimpanan

\begin{tabular}{lllllll}
\hline & \multicolumn{7}{c}{ Penyimpanan Hari ke- } \\
\cline { 2 - 7 } Perlakuan & \multicolumn{7}{c}{0} & \multicolumn{3}{c}{3} & 6 \\
\cline { 2 - 7 } & $\begin{array}{l}\text { Kadar Air } \\
(\%)\end{array}$ & $\begin{array}{l}\text { FFA } \\
(\%)\end{array}$ & $\begin{array}{l}\text { Kadar } \\
\text { Air }(\%)\end{array}$ & $\begin{array}{l}\text { FFA } \\
(\%)\end{array}$ & $\begin{array}{l}\text { Kadar Air } \\
(\%)\end{array}$ & $\begin{array}{l}\text { FFA } \\
(\%)\end{array}$ \\
\hline Pati 1\% & 25,73 & 0,79 & $23,07 \mathrm{a}$ & $0,83 \mathrm{a}$ & $22,41 \mathrm{a}$ & $2,25 \mathrm{f}$ \\
Pati 1,5\% & 26,53 & 0,74 & $24,15 \mathrm{ab}$ & $0,94 \mathrm{ab}$ & $23,88 \mathrm{bc}$ & $2,07 \mathrm{e}$ \\
Pati 2\% & 27,19 & 0,69 & $25,16 \mathrm{~b}$ & $0,99 \mathrm{ab}$ & $24,94 \mathrm{bc}$ & $1,74 \mathrm{c}$ \\
Pektin 1\% & 27,09 & 0,85 & $25,38 \mathrm{~b}$ & $1,05 \mathrm{~b}$ & $25,08 \mathrm{c}$ & $1,15 \mathrm{a}$ \\
Pektin 1,5\% & 27,11 & 0,84 & $25,55 \mathrm{bc}$ & $1,08 \mathrm{~b}$ & $25,24 \mathrm{c}$ & $1,10 \mathrm{a}$ \\
Pektin 2\% & 28,82 & 0,82 & $27,26 \mathrm{c}$ & $1,13 \mathrm{~b}$ & $27,03 \mathrm{~cd}$ & $1,06 \mathrm{a}$ \\
CMC 1\% & 28,71 & 0,86 & $27,22 \mathrm{c}$ & $1,23 \mathrm{~b}$ & $26,98 \mathrm{~cd}$ & $1,99 \mathrm{de}$ \\
CMC 1,5\% & 30,55 & 0,85 & $29,17 \mathrm{~d}$ & $1,44 \mathrm{c}$ & $28,94 \mathrm{~d}$ & $1,91 \mathrm{~d}$ \\
CMC 2\% & 32,87 & 0,81 & $31,59 \mathrm{e}$ & $1,93 \mathrm{~d}$ & $31,28 \mathrm{~d}$ & $1,61 \mathrm{~b}$ \\
\hline Anc
\end{tabular}

Angka yang diikuti oleh huruf abjad yang berbeda menunjukkan perbedaan nyata berdasarkan uji Duncan $\alpha=1 \%$.

Dodol merupakan makanan yang berkadar lemak tinggi. Hal tersebut yang menyebabkan kerusakan akibat ketengikan mudah terjadi. Menurut Feriska (2014) Proses ketengikan pada produk pangan menandakan produk yang telah mengalami kerusakan. semakin tinggi kadar FFA dalam produk semakin tinggi pula hidrolisis yang terjadi. Terbentuknya asam lemak bebas berkaitan dengan kandungan kadar air dalam dodol yang menyebabkan terjadinya proses hidrolisis. Menurut Gunawan (2003) akibat dari proses hidrolisis menyebabkan kemunduran mutu dodol karena rusaknya sejumlah asam lemak essensial dalam lemak dan kerusakan vitamin.

Berdasarkan Tabel 3 dapat dilihat bahwa semakin tinggi konsentrasi pengental yang ditambahkan, angka TPC semakin menurun karena ketebalan lapisan coating yang semakin tebal. Semakin tebalnya lapisan coating menyebabkan kemampuannya dalam menahan masuknya oksigen ke dalam dodol menjadi lebih baik. 
Tabel 3. Perubahan Mikrobiologi Dodol Selama Penyimpanan

\begin{tabular}{llll}
\hline \multirow{2}{*}{ Perlakuan } & \multicolumn{3}{c}{ TPC (Cfu/g) Penyimpanan Hari ke- } \\
\cline { 2 - 4 } & 0 & 3 & 6 \\
\hline Pati 1\% & $2,0 \times 10^{3}$ & $1,2 \times 10^{5} \mathrm{c}$ & $1,9 \times 10^{5} \mathrm{c}$ \\
Pati 1,5\% & $2,0 \times 10^{3}$ & $9,0 \times 10^{4} \mathrm{bc}$ & $1,3 \times 10^{5} \mathrm{c}$ \\
Pati $2 \%$ & $1,0 \times 10^{3}$ & $6,9 \times 10^{4} \mathrm{~b}$ & $9,3 \times 10^{4} \mathrm{c}$ \\
Pektin 1\% & $1,0 \times 10^{3}$ & $6,4 \times 10^{4} \mathrm{ab}$ & $8,8 \times 10^{4} \mathrm{bc}$ \\
Pektin 1,5\% & $1,0 \times 10^{3}$ & $5,3 \times 10^{4} \mathrm{ab}$ & $5,6 \times 10^{4} \mathrm{~b}$ \\
Pektin 2\% & $1,0 \times 10^{3}$ & $4,4 \times 10^{4} \mathrm{a}$ & $4,9 \times 10^{4} \mathrm{a}$ \\
CMC 1\% & $2,0 \times 10^{3}$ & $1,1 \times 10^{5} \mathrm{c}$ & $1,1 \times 10^{5} \mathrm{c}$ \\
CMC 1,5\% & $2,0 \times 10^{3}$ & $7,3 \times 10^{4} \mathrm{bc}$ & $9,0 \times 10^{4} \mathrm{bc}$ \\
CMC 2\% & $1,0 \times 10^{3}$ & $5,9 \times 10^{4} \mathrm{ab}$ & $6,3 \times 10^{4} \mathrm{ab}$ \\
\hline
\end{tabular}

Angka yang diikuti oleh huruf abjad yang berbeda menunjukkan perbedaan nyata berdasarkan uji Duncan $\alpha=1 \%$.

Menurut Nasyiah (2014) lapisan coating yang tebal memiliki permeabilitas gas yang rendah, sehingga laju gas seperti O2 yang berperan dalam pertumbuhan mikroorganisme dapat terhambat. Edible coating berperan menghambat perpindahan oksigen, sehingga mikroba aerob tidak dapat tumbuh dan berkembang. Pertumbuhan mikroba dipengaruhi oleh adanya perpindaan oksigen selama penyimpanan (Khofifah, 2012). Menurut Fortez (2011) menyatakan bahwa pektin dengan konsentrasi $2 \%$ memiliki permeabilitas oksigen sebesar $19,49 \mathrm{~cm}^{3} \mu \mathrm{m} \mathrm{m}-2 \mathrm{dkPa}$. Nilai tersebeut lebih rendah bila dibandingkan dengan methyl cellulose sebesar $286,43 \mathrm{~cm}^{3} \mu \mathrm{m} \mathrm{m}-2 \mathrm{dkPa}$.

Berdasarkan Tabel 4, susut bobot cenderung semakin menurun seiring dengan semakin tingginya konsentrasi bahan pengental yang ditambahkan pada lapisan coating. Semakin banyak air yang terikat atau terperangkap dalam lapisan coating, menyebabkan air bebas semakin rendah sehingga air yang teruapkan selama pengeringan semakin kecil. Menurut Donald (2000) CMC memiliki gugus hidroksil dan gugus karboksil yang dapat mengikat air. Semakin banyak CMC yang ditambahkan maka semakin banyak air yang terikat sehingga air bebas menjadi berkurang.

Penurunan tekstur yang terjadi pada hari ke-0 dapat disebabkan karena semakin tinggi konsentrasi bahan pengental yang ditambahkan, kemampuan hidrokoloid dalam mengikat atau memerangkap air pada lapisan coating semakin meningkat sehingga berpengaruh pada tekstur. Peningkatan tekstur pada hari ke-3 dapat disebabkan karena pada hari ke-0 lapisan coating yang masih belum mengering menyebabkan tekstur yang lebih rendah atau lunak sehingga, lapisan coating yang telah mengering menjadi lebih keras. 
Tabel 4. Perubahan Fisik Dodol Selama Penyimpanan

\begin{tabular}{|c|c|c|c|c|c|}
\hline \multicolumn{6}{|c|}{ Penyimpanan Hari ke- } \\
\hline \multirow{2}{*}{ Perlakuan } & \multicolumn{2}{|l|}{0} & \multicolumn{2}{|l|}{3} & \multirow{2}{*}{$\begin{array}{l}6 \\
\text { Tekstur } \\
(\mathrm{N} / \mathrm{mm})\end{array}$} \\
\hline & $\begin{array}{l}\text { Tekstur } \\
(\mathrm{N} / \mathrm{mm})\end{array}$ & $\begin{array}{l}\text { Susut } \\
\text { Bobot (\%) }\end{array}$ & $\begin{array}{l}\text { Tekstur } \\
(\mathrm{N} / \mathrm{mm})\end{array}$ & $\begin{array}{l}\text { Susut } \\
\text { Bobot (\%) }\end{array}$ & \\
\hline Pati $1 \%$ & $8,36 \mathrm{f}$ & 3,18 & $8,64 \mathrm{de}$ & 1,37 & $8,74 \mathrm{~d}$ \\
\hline Pati 1,5\% & $8,31 \mathrm{f}$ & 2,37 & $8,77 \mathrm{e}$ & 0,85 & $8,86 \mathrm{~d}$ \\
\hline Pati $2 \%$ & $7,81 \mathrm{e}$ & 2,02 & $8,41 d$ & 0,61 & $8,49 \mathrm{~cd}$ \\
\hline Pektin 1\% & 7,78de & 1,93 & $8,44 \mathrm{~d}$ & 0,38 & $8,52 \mathrm{~cd}$ \\
\hline Pektin $1,5 \%$ & $7,57 \mathrm{~d}$ & 1,79 & $8,27 \mathrm{~cd}$ & 0,37 & $8,35 \mathrm{c}$ \\
\hline Pektin $2 \%$ & $7,36 \mathrm{c}$ & 1,70 & $8,11 \mathrm{c}$ & 0,36 & $8,18 \mathrm{c}$ \\
\hline CMC 1\% & $7,44 \mathrm{~cd}$ & 1,60 & $8,16 \mathrm{c}$ & 0,48 & $8,24 \mathrm{c}$ \\
\hline CMC 1,5\% & $6,99 \mathrm{~b}$ & 1,30 & $7,74 \mathrm{~b}$ & 0,44 & $7,82 \mathrm{~b}$ \\
\hline CMC $2 \%$ & $5,92 \mathrm{a}$ & 1,04 & $6,71 \mathrm{a}$ & 0,43 & $6,78 \mathrm{a}$ \\
\hline
\end{tabular}

Angka yang diikuti oleh huruf abjad yang berbeda menunjukkan perbedaan nyata berdasarkan uji Duncan $\alpha=1 \%$.

Peningkatan tekstur pada hari ke-6 tidak sebesar seperti pada hari ke-3 karena edible coating telah memberikan perlindungan atau pengaruh terhadap produk yang dilapisinya. Menurut Riska (2018) faktor edible coating yang melapisi dodol sangat mempengaruhi tekstur karena fungsi edible coating adalah sebagai bahan pelapis yang mampu menahan laju transmisi uap air yang menyebabkan produk tidak cepat kering.

Tabel 5. Perubahan Warna Dodol Selama Penyimpanan

\begin{tabular}{|c|c|c|c|c|c|c|}
\hline \multirow{3}{*}{ Perlakuan } & \multicolumn{6}{|c|}{ Penyimpanan Hari Ke ${ }^{-}$} \\
\hline & \multicolumn{3}{|c|}{0} & \multicolumn{2}{|l|}{3} & 5 \\
\hline & $\mathrm{L}$ & $\mathrm{a}(+)$ & $\mathrm{L}$ & $\mathrm{a}(+)$ & $\mathrm{L}$ & $\mathrm{a}(+)$ \\
\hline Pati 1\% & $52,17 \mathrm{~d}$ & $6,23 \mathrm{~d}$ & $51,17 \mathrm{~d}$ & 7,77 & 45,83 & 8,73 \\
\hline Pati $1,5 \%$ & $52,80 \mathrm{~d}$ & $6,47 \mathrm{~d}$ & $52,30 \mathrm{e}$ & 7,63 & 49,20 & 8,60 \\
\hline Pati $2 \%$ & $53,26 \mathrm{~d}$ & $6,47 \mathrm{~d}$ & $52,46 \mathrm{e}$ & 7,30 & 49,90 & 8,03 \\
\hline Pektin 1\% & $42,20 \mathrm{a}$ & $5,70 \mathrm{~b}$ & $30,16 \mathrm{a}$ & 6,30 & 29,23 & 6,86 \\
\hline Pektin $1,5 \%$ & $41,90 \mathrm{ab}$ & $5,50 \mathrm{ab}$ & $30,70 \mathrm{ab}$ & 6,10 & 29,86 & 6,63 \\
\hline Pektin $2 \%$ & $41,26 \mathrm{~b}$ & $5,26 \mathrm{a}$ & $30,76 \mathrm{~b}$ & 5,83 & 30,10 & 6,67 \\
\hline CMC 1\% & $43,90 \mathrm{c}$ & $6,56 \mathrm{~d}$ & $42,30 \mathrm{c}$ & 7,53 & 40,83 & 8,26 \\
\hline CMC $1,5 \%$ & $43,56 \mathrm{c}$ & $6,27 \mathrm{~cd}$ & $42,26 \mathrm{c}$ & 7,23 & 41,06 & 8,16 \\
\hline CMC 2\% & $43,30 \mathrm{c}$ & $6,01 \mathrm{c}$ & $42,60 \mathrm{c}$ & 6,90 & 41,60 & 7,80 \\
\hline
\end{tabular}

Angka yang diikuti oleh huruf abjad yang berbeda menunjukkan perbedaan nyata berdasarkan uji Duncan $\alpha=1 \%$. 
Berdasarkan Tabel 5, kecerahan cenderung semakin menurun seiring dengan lamanya waktu penyimpanan. Perubahan tingkat kecerahan dapat disebabkan karena adanya perubahan warna menjadi lebih gelap karena adanya proses oksidasi yang menyebabkan terjadinya penurunan tingkat kecerahan. Menurut Ketaren, (2008) bahwa perubahan warna menjadi gelap selama penyimpanan disebabkan karena adanya oksidasi. Selain itu, dapat disebabkan karena kontaminasi udara ataupun bakteri akan memberikan warna yang beragam setelah terjadinya penyimpanan.

Warna yang dihasilkan bernilai a (+) yang artinya kecenderungan berwarna mendekati merah. Hal ini terjadi karena proses pemasakan gula merah saat proses pembuatan dodol memfasilitasi terjadinya proses maillard dan karamelisasi sehingga terbentuk warna mendekati merah. Pemanasan bahan berkadar gula tinggi bersama dengan protein akan memfasilitasi terjadinya reaksi browning non enzimatis maillard (Winarno, 2004).

Tingkat kemerahan dodol semakin menurun seiring dengan meningkatnya konsentrasi bahan pengental yang ditambahkan. Hal tersebut dapat disebabkan karena semakin tinggi konsentrasi bahan pengental, lapisan yang terbentuk semakin tebal sehingga menjadi lebih buram dan menjadikan warna kemerahan dodol menjadi semakin kurang terihat. Namun lain halnya dengan perlakuan pati pada penyimpanan hari ke-0 dimana semakin tinggi konsentrasi bahan pengental yang ditambahkan, warna kemerahan semakin meningkat. Hal ini dapat terjadi karena dengan adanya penambahan pati menyebabkan lapisan coating menjadi transparan, sehingga semakin banyak konsentrasi pati yang ditambahkan, proses gelatinisasi yang menyebabkan pasta pati menjadi bening semakin meningkat.

Skor kenampakan berhubungan dengan warna, bentuk maupun ukuran produk. Warna produk yang menarik maka menambah daya tarik panelis pada nilai organoleptik dodol. Menurut Winarno (2008) kenampakan yang meliputi, warna, bentuk dan ukuran merupakan atribut pertama kali akan dinilai oleh konsumen dan seringkali menentukan penilaian secara keseluruhan produk. Peranan aroma dalam makanan sangat penting karena turut memberikan pengaruh terhadap tingkat penerimaan konsumen terhadap makanan. Aroma tidak hanya ditentukan oleh satu komponen tetapi juga oleh beberapa komponen tertentu yang menimbulkan bau khas serta perbandingan beberapa komponen (Damayanti, 2000). 


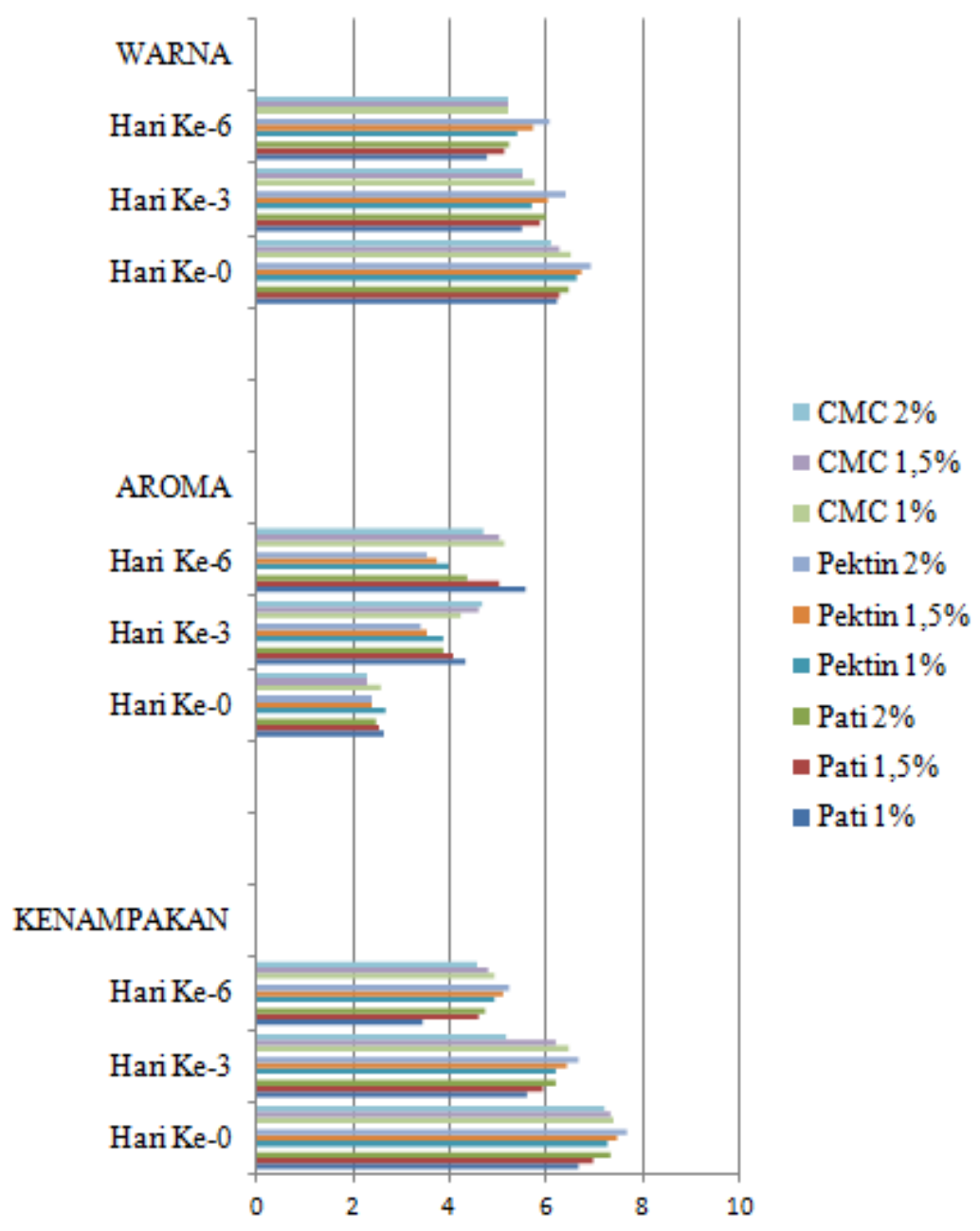

Gambar 1. Histogram Rerata Skor Organoleptik Dodol Selama Penyimpanan Keterangan skor kenampakakan:

$1=$ Amat sangat tidak menarik

$2=$ Sangat tidak menarik

3= Tidak menarik

Keterangan skor aroma:

1=Amatsangat tidak tengik

$2=$ Sangat tidak tengik

$3=$ Tidak tengik

Keterangan skor kesukaan:

1=Amatsangat tidak suka

$2=$ Sangat tidak suka

$3=$ Tidak suka

$$
\begin{array}{ll}
4=\text { Sedikit tidak menarik } & 7=\text { Menarik } \\
5=\text { Netral } & 8=\text { Sangat menarik } \\
6=\text { Sedikit menarik } & 9=\text { Amat sangat menarik }
\end{array}
$$

4= Sedikit tengik

$7=$ Menarik

$5=$ Netral

$8=$ Sangat tengik

$6=$ Sedikit tengik

$9=$ Amat sangat tengik

$4=$ Sedikit suka

$5=$ Netral

$7=$ Menarik

$8=$ Sangat suka

$9=$ Amat sangat suka

Semakin tinggi konsentrasi bahan pengental yang ditambahkan ketebalan lapisan coating semakin tebal sehingga perlindungan terhadap dodol semakin baik selama penyimpanan. Namun apabila larutan coating terlalu 
kental, dan kemampuan agen pengental dalam mengikat air yang terlalu besar dapat menyebabkan kerusakan karena perubahan akibat adanya proses kimiawi maupun mikrobiologi sehingga menurunkan rerata skor kesukaan panelis. Apabila larutan coating terlalu encer menyebabkan lapisan coating yang terbentuk terlalu tipis dan berakibat kurang optimal dalam melindungi produk sehingga cepat mengalami perubahan akibat kerusakan.

\section{Penentuan Perlakuan Terbaik}

Penentuan perlakuan terbaik dodol yang dilapisi edible coating dengan penambahan bahan pengental dilakukan dengan menggunakan metode indeks efektivitas (De Garmo, 1984). Berdasarkan hasil uji perlakuan terbaik menunjukkan bahwa ranking tertinggi adalah perlakuan pektin dengan konsentrasi $2 \%$ sedangkan yang terendah adalah perlakuan pati konsentrasi $1 \%$.

Tabel 6. Perbandingan Perlakuan Terbaik dengan Kontrol

\begin{tabular}{llrrr}
\hline \multirow{2}{*}{ Analisa } & \multicolumn{2}{c}{ Rerata } & \multirow{2}{*}{ T.Hitung } & \multirow{2}{*}{ NOTASI } \\
\cline { 2 - 5 } & Pektin $2 \%$ & Kontrol & & \\
\hline Viskositas Larutan Coating 239,50 & 29,20 & 55,34 & $* *$ \\
\hline Kadar Air & 27,03 & 19,56 & 27,03 & $* * *$ \\
Susut Bobot & 0,35 & 5,29 & 13,38 & $* *$ \\
FFA (Free Fatty Acid) & 1,06 & 3,11 & 28,08 & $* *$ \\
TPC (Total Plate Count) & $4,9 \times 10^{4}$ & $9,7 \times 10^{5}$ & 41,99 & $* *$ \\
Tekstur & 8,18 & 10,15 & 5,71 & $* *$ \\
Warna (L) & 30,10 & 24,90 & 3,42 & $* *$ \\
Warna (a+) & 6,67 & 8,00 & 1,48 & tn \\
Warna (b+) & 14,06 & 7,10 & 10,52 & $* *$ \\
Kenampakan & 4,77 & 5,77 & 2,45 & tn \\
Aroma & 3,53 & 6,17 & 6,17 & $* *$ \\
Kesukaan & 4,07 & 7,10 & 4,80 & $* *$ \\
\hline T.Tabel & \multicolumn{5}{c}{2,776} & \\
\hline
\end{tabular}

Keterangan: tn: tidak nyata

Berdasarkan Tabel 6, dapat diketahui bahwa perlakuan terbaik (Pektin 2\%) dilakukan uji $\mathrm{T}$ yang dibandingkan dengan sampel kontrol (edible coating tanpa penambahan bahan pengental) memberikan perbedaan yang signifikan terhadap viskositas, kadar air, susut bobot, FFA (Free Fatty Acid), TPC (Total Plate Count), tekstur, warna (L dan b+), serta organoleptik (aroma, kesukaan). Namun memberikan perbedaan yang tidak nyata terhadap parameter kenampakan dan tingkat kemerahan $(\mathrm{a}+)$ dodol. Hal tersebut dapat disebabkan karena tanpa adanya bahan pengental, viskositas larutan coating 
menjadi encer dan kemampuannya dalam melapisi produk menjadi lemah. Menurut Budiman (2011), Polisakarida larut air merupakan senyawa polimer berantai panjang yang dilarutkan kedalam air, dengan tujuan mendapatkan viskositas larutan yang cukup kental. Komponen-komponen inilah yang akan berperan untuk mendapatkan kekerasan, kepadatan, kualitas ketebalan, viskositas, adhesivitas, dan kemampuan pembentukan gel.

\section{KESIMPULAN}

Berdasarka penelitian ini, didapatkan beberapa kesimpulan yaitu jenis pengental pati, pektin dan CMC memberikan pengaruh yang nyata terhadap viskositas larutan coating, kadar air dodol, susut bobot, FFA (Free Fatty Acid), TPC (Total Plate Count), tekstur, warna ( L dan b+), aroma dan kesukaannamun berpengaruh tidak nyata terhadap tingkat kemerahan (a+) kenampakan dodol. Konsentrasi bahan pengental memberikan pengaruh terhadap kualitas edible coating yang melapisi dodol, karena semakin tinggi konsentrasi bahan pengental yang ditambahkan pada edible coating, ketebalan lapisan coating menjadi lebih meningkat sehingga kemampuannya dalam melapisi produk menjadi lebih baik. Perlakuan terbaik pada P2K3 (Pektin konsentrasi 2\%) untuk mempertahankan kualitas mutu dodol selama penyimpanan suhu ruang hingga

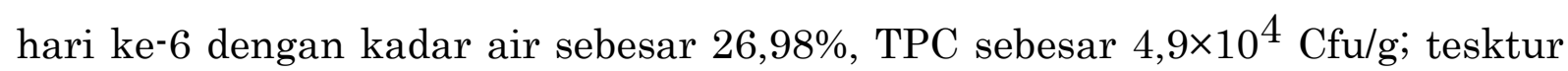
sebesar 8,81 N/mm, susut bobot sebesar 0,355\%; FFA sebesar 1,06\%; warna L (kecerahan) sebesar 30,10; warna a+ (kemerahan) 6,67; warna b+ (kekuningan) 14,10; skor aroma 3,53 yang berarti sedikit tidak tengik; skor kenampakan 5,23 yang berarti netral dan skor kesukaan sebesar 6,07 yang berarti sedikit suka.

\section{REFERENSI}

Amaliya, R.R. \& W.D.R. Putri. 2014. Karakteristik Edible Film dari Pati Jagung dengan Penambahan Filtrat Kunyit Putih sebagai Antibakteri. Jurnal Pangan dan Agroindustri; 2(3):4353.Semarang.

Ann-Charlott Eliasson. 2004. Starch in Food. Woodhead Publishing Limited Cambridge. England.

Badan Pusat Statistik. 2013. Kabupaten Lima Puluh Kota dalam Angka 2013. Sarilamak.

Badan Standarisasi Nasional. 2013. SNI 01-2986-2013. Dodol Beras Ketan. Badan Standarisasi Nasional. Jakarta.

Bird, T., 2000. Kimia Fisik untuk Universitas, Terjemahan: K. I. Tjeen., PT Gramedia, Jakarta.

Bourtoom, 2007. Pengaruh Jenis Plasticizer Terhadap Sifat Fisik dan Mekanik Plastik Biodegradable (terjemah). Universitas Gajah Madah.

Chaplin, M.Fand C. Bucke. 2004. Enzyme Technology. Cambridge University Press, Cambridge, 378-380. Great Britain.

De Garmo, E.P.W.G. Sullivan dan J.R. Canada. 1984. Engineering Economy The 
$7^{\text {th }}$ Edition. Macmillan Publishing Comp., New York.

Direktorat Pengolahan Pangan Hasil Pertanian. 2005. Pengembangan Usaha Pengolahan Tepung Tapioka. Departemen Pertanian, Jakarta.

Fortez, L.C.B., K.K. Ramos, T.C.Sivi dan F.P.C. Queiroz. 2011. Biodegradable Edible Film from Renewable Sources- Potential for Their Application in Fried Foods. American Journal of Food Technology. 6(7).USA.

Fuadi,F. 2011 . Ekstraksi Pektin dari Kulit Pisang Kepok dengan Pelarut Asam Klorida. Jurnal Teknik Kimia No. 5, Vol. 17.

Goldberg, David E.2004. Kimia Untuk Pemula. Erlangga. Jakarta.

Guichard, E. S., A, Issanchou., Descovieres dan P. Etievant. 2000. Pectin Concentration, Molekular Weight and Degree of Esterification. Influence on Volatile Composition and Sensory Caracteristic of Strawberry Jam. J. Food Science, 56:1621.USA.

Hariyadi, 2008 . Kimia danTeknologi Pati (Manuskripi Bahan Pengajaran).PPS UGM Press. Yogjakarta

Konservasi Lahan Kering. 3(2):21- 23.Jakarta.

Khofifah, I. 2012. Pemanfaatan Natrium Alginat sebagai Edible Coating untuk Menghambat Kemunduran Mutu Ikan Bandeng (Chanos chanos Forsk) Asap Selama Penyimpanan Suhu Ruang. Skripsi. Universitas Diponegoro, Semarang.

Krochta, J. M. dan De Mulder- Johnston, C. 1997. Edible and biodegradable polymer films: challenges and opportunities. J. Food Tech 51: 61-73.

Laili, Riskalatul.2019. Kajian Penambahan Ekstrak Kayu manis, Sakarin dan Aspartam pada Edible Film Pati Singkong dan Substitusi Rumput Laut (Euchema cottoni). Teknologi Pangan. Fakultas PertanianPeternakan.UMM.Malang.

Meyer, H., 2000. Food Chemistry. Reinhold Publishing Corporation.New York.

Musaddad, D,. dan Hartuti, N,. 2003. Produk Olahan Tomat, seri agribisnis. Penebar Swadaya, Jakarta.

Sitompul, K. 2017. Sifat Fisik Edible Film Kolang Kaling. Jurnal Pangan dan Agroindustri Vol.5 No.1:13-25. Jakarta.

Skurtys, O., C. Acevedo, F. Pedreschi, J. Enrions, F. Osorio, dan J.M. Aquilera. 2011. Food hydrocolloid edible films and coating. Journal of Food Research International, 39: 840-646.

Suryani. 2015. Modifikasi Pati Singkong. Pada Proses Pembuatan Marshmallow. Jurnal Pangan dan Agroindustri Vol. 3 No 2 p.723-733. Jakarta.

Syarifuddin, A., 2015, Karakteristik Edible Film dari Pektin Albedo Jeruk Bali dan Pati Garut. Universitas Brawijaya.Malang.

Taggart, P. 2004. Starch as an ingredients : manufacture and applications. Di dalam: Ann Charlotte Eliasson (ed). Starch in Food: Structure, Function, and Application. CRC Press, Baco Raton, Florida.

Tarigan, J, dan Gaban, J.2009. Analisa Thermal dan Komponen Kimia KolangKaling. Jurnal Biologi Sumatra.4:1.

Tazwir, D. L. Ayudiarti, dan Suryanti. 2010. Pengaruh Penggunaan Asam Klorida Terhadap Mutu Gelatin Tulang Ikan Kakap Putih (Lates calcarifer). Jakarta. 
Wijandi, S. 1976. Ilmu Pengetahuan Bahan Umbi- umbian. Departemen Teknologi Hasil Pertanian. Institut Pertanian Bogor.Bogor.

Winarno, F.G. 2008. Kimia Pangan dan Gizi: Edisi Terbaru. Gramedia. Pustaka Utama. Jakarta.

Wong. D.W.S., W.M. Camirand and A.E. Paulath. 1994. Development of Edible Penyalut For Minimally Processed Fruit and Vegetables, Di Dalam: Krochta Et Al. (Ed).Edible Penyaluts and Films To Improve Food Quality.Technomic Publ Co. Inc.Lancaster-Basel. Pennsylvania. USA. 